\title{
Looking at Both Sides of the Coin: Revisiting the Role of Country of Origin in International Business
}

\author{
Alexander Josiassen \\ Victoria University, Australia \\ Richard Fletcher \\ University of Western Sydney, Australia
}

\begin{abstract}
In international business the country-of-origin and psychological distance concepts play crucial roles. Both have been extensively investigated by researchers. However, the notion that they both deal with countryperceptions as seen from the seller and buyer respectively have mostly been overlooked in the extant literature. In this article, the authors argue that the two concepts are critical to market success and that firms must consider their joint influence on the buyer-seller relationship as well as on the individual deal. The issue is further illustrated via a case study. Conceptually, the holistic network-perspective which the authors advocate is a distinct departure from previous research-traditions in either area.
\end{abstract}

\section{Keywords}

Psychological Distance, Country-of-origin, International Marketing, International Management, Consumer Behaviour, Case study.

\section{Introduction}

That origins differ is the fundamental premise of international business. Concepts such as country-oforigin (COO) and psychological distance (PD) both rely on this basic premise. COO refers to the buyer's perception of the seller's origin and PD refers to the seller's perception of the buyer's origin. While any international trade involves at least two parties the extant literature in each of these research areas has tended to examine them separately (e.g. O'Grady \& Lane, 1996; Peterson \& Jolibert, 1995). There is a need for these concepts to be explored jointly so as to better portray how international business actually takes place. In this paper, we develop a more holistic perspective of doing business in international markets that views the relationship between the exporting firm and the importing firm as the unit of analysis. We also develop four illustrative propositions which address this holistic view. Both psychological distance and country of origin will be treated as perceptual constructs - viz they reflect the way individuals perceive origins or products/services identified with those origins regardless of whether the individual is a manager representing an organization or a consumer. We organize the paper as follows: First we review the extant literature relating to PD and COO. Next we make a case for a joint consideration of $\mathrm{PD}$ and $\mathrm{COO}$ and illustrate the linkage with two case examples. Then we discuss the implications for theory and practice, and present four illustrative propositions for future research derived

Copyright (C) 2010 Victoria University. This document has been published as part of the Journal of Business Systems, Governance and Ethics in both online and print formats. Educational and non-profit institutions are granted a nonexclusive licence to utilise this document in whole or in part for personal or classroom use without fee, provided that correct attribution and citation are made and this copyright statement is reproduced. Any other usage is prohibited without the express permission of the publisher. from the PD and COO.

\section{Psychological Distance}

Psychological distance refers to the perception of the differences between the home and the foreign country (O'Grady and Lane, 1996). It has been defined "as the sum of factors preventing or disturbing the 
flows of information between firm and markets" (Johansson and Wiedersheim-Paul 1975) or as "the distance between the home market and a foreign market, resulting from the perception of both cultural and business differences" (Evans and Mavondo 2002). Chetty and Campbell-Hunt (2004) specify these differences as language, culture, political system, business practices, industrial development and educational system and Dow and Karunaratna (2006) found the differences to be language, religion, education, level of country's development and political systems. In international marketing, for the seller the psychological distance impacts on the desire to undertake business with buyers from other countries and on the willingness to commit resources to such a venture.

As such, PD is a perceptual construct that operates at the individual level (Harzing, 2003). It is often measured using indices of cultural distance (Fletcher and Bohn 1998) and this is rationalised as being a surrogate for psychological distance on the grounds that other factors causing psychological distance are also influenced by culture. In most cases, the measures of cultural distance have been based on Hofstede's 1980 measures (Fletcher and Bohn, 1998, Evans and Mavondo, 2002) although more recently, $\mathrm{Ng}$ et al, (2007) found that Swartz's values were a better measure of cultural distance. Recently the use of cultural distance as a proxy for PD has been challenged. The critique is that whereas PD should be measured at the individual level due to it being a perceptual construct, the measure used to measure cultural distance is based on Hofstede (1980) which is a national level measure (Sousa and Bradley 2003).

Brewer (2004) argues that familiarity with the potential overseas market operates as a moderating variable on psychological distance as a perceptual construct. He points out that despite major cultural differences, Japan is Australia's major export market, China is growing as a market for Australia faster than any other overseas market and there has been a major shift to east and south-east Asian countries as markets for Australian goods and services over the last 30 years. None of these markets are close to Australia in psychological distance terms as measured by Fletcher and Bohn (1998). Brewer (2004) explains this apparent contradiction as being due to market familiarity which includes commercial ties, political ties, historic ties, geographic ties, social ties, information ties and levels of development which he measures via a 16 item index.

According to Evans and Mondavo (2002), apart from national culture, business factors also impact on psychological distance. These indictors of business distance include:

- politics (factors such as membership of regional trade groupings; stability within the state and within local areas of the state)

- economics (Gross National Product level; economic stability; degree of government control over business; extent of currency fluctuations)

- business practices (the structure of the market, difficulties of access; differences in business practices such as attitude to bribery)

- language differences (the script, the extent of tonality; how the language is written; the pattern of discourse).

Here one would add, most importantly, cultural understanding.

Evans and Mondavo (2002) measured cultural distance using Hofstede and Bond's (1988) five dimensions - power distance, individuality, masculinity, uncertainty avoidance and long-term orientation. They found a very high correlation between measures of cultural distance and business distance. Their overall conclusion was that psychological distance as a summary construct explains a significant proportion of the variance in financial performance and strategic effectiveness in foreign markets.

Some specificity here would be helpful.

Psychological distance is also likely to affect evaluation of potential opportunities for business in a country. Perceptions of psychological distance however are likely to be modified by both additional information about a country and experience in dealing with people from that country. Sousa and Bradley (2003) proposed a theoretical framework for psychological distance. This framework shows that cultural distance, experience and values are responsible for perceptions of psychological distance. 
This fits the notion that psychological distance is a perceptual construct influenced by values as reflected in culture and modified by experience.

\section{Country-of-Origin Image}

Recent research confirms the importance of the COO construct to buyers' when evaluating products for purchase, and thus to marketers (Josiassen \& Harzing 2008). Like PD, COO is also a perceptual construct (Gurhan-Canli \& Maheswaran, 2000a, 2000b; Han, 1989; Knight \& Calantone, 2000; Verlegh \& Steenkamp, 1999). The fact that the concept is often referred to as country of origin image, underlines its perceptual nature. $\mathrm{COO}$ image has been the subject of a large volume of research (for reviews, see Al-Sulaiti \& Baker, 1998; Bilkey \& Nes, 1982; A. P. Josiassen \& Karpen, 2007; Ozsomer \& Cavusgil, 1991; Peterson \& Jolibert, 1995; Pharr, 2005; Verlegh \& Steenkamp, 1999). Originally regarded as a reflection of the country in which goods were wholly manufactured (Holzmuller and Lenz, 2004), the concept has now acquired a broader currency and can embrace country-of-assembly, country-of-design, country-of-ownership or even the country associated with the original brand $(\mathrm{Li}$, Murray, \& Scott, 2000; Tse \& Gorn, 1993). As such, the increasing practice of global sourcing frequently results in hybrid products with multiple origins. Regardless of the form it takes, there will still be, apart from truly global products and global brands, a perceptual linking with a country with which the product is associated in the mind of the buyer (Usunier, 2006). Its effect is the influence that the country-of-association has on the positive or negative perception of the product or service. It serves as a signal for product quality and performance (Han, 1989). It can be a marketing asset as when the captious cues of a $\mathrm{COO}$ are used for a product or service with no direct association with that country (Fletcher and Bell 2002). In essence, COO generally refers to ways in which the buyer perceives an overseas source of supply in terms of its attractiveness (Josiassen and Harzing 2008).

The COO sometimes serves as a substitute in the decision making process when there is a lack of specific information about a product or service as offered from overseas. The influence of the construct is likely to vary in inverse proportion to the extent that information about the attributes of a product or service that is available to the buyer (Acharya and Elliott 2001). For many years the role of product familiarity in terms of moderating the $\mathrm{COO}$ effect was unclear. As such, Han and Terpstra (1998), asserted that COO plays a major role when the buyer is unfamiliar with the foreign source of the product. Others (Johansson, Douglas, \& Nonaka, 1985) found that COO plays a greater role when the buyer is familiar with the product category. Recently this long standing issue was resolved; in support of Han and Terpstra (1998) it was confirmed that higher product familiarity decreases consumers' propensity to rely on the COO cue (A. Josiassen, Lukas, \& Whitwell, 2008). With regard to the effects of the $\mathrm{COO}$ cue, there is strong evidence (Peterson and Jolibert 1995) that COO information can influence a given buyer's perceptions. Extant research (Gurhan-Canli \& Maheswaran, 2000a, 2000b) finds that beliefs about a product and its COO can be descriptive and based on direct recent experience with the product; inferential based on past experience with the product and/or informational based on external sources of information such as friends/relatives or advertising. In addition, buyers often have product-related stereotypes about countries that are based on hearsay or myth.

Another issue is whether the COO image is formed without direct experience with the products from a given origin, but merely on the basis of other 'evidence' (such as the 'halo-effect') or whether the $\mathrm{COO}$ image is a summary of a number of direct experiences with products and services from that country (summary-effect) (Han, 1989). In general, the 'halo' construct operates where consumers are unfamiliar with the product and the 'summary' construct operates where consumers know the product or service and then form conclusions about the country of origin based on their experience with the product (A. Josiassen et al., 2008).

Research (Okechuku \& Onyemah, 1999) further shows that that buyers are more receptive to products from developed countries, less receptive to products from developing countries and negative towards products from the least developed countries, depending on the level of sophistication of the product concerned. This reflects the notion that products are perceived as being of higher quality when produced in developed countries (Bilkey and Ness 1982) and that differences in economic 
development create an important contingency within which the $\mathrm{COO}$ effect operates (Verlegh and Steenkamp 1999).

COO perceptions may change over time both with increasing experience regarding products and services from a country. Alternatively perceptions may be influenced as the country moves to a higher stage of development with a consequent increase in product quality and product performance (Nagashima, 1977). For the global or trans-national company, COO may influence location decisions and the degree of value adding to be undertaken in a specific overseas market. Acharya and Elliott (2001) found that shifting the production location to a country with a less favourable COO image may result in lower consumer confidence even for well-known brands.

The impact of $\mathrm{COO}$ on decision-making may also vary according to the extent of consumer ethnocentrism in a market (Shimp \& Sharma, 1987). The concept of consumer ethnocentrism is closely related to the concept of patriotism, which is a value that reflects a willingness to love, support and defend one's country. Patriotism has been shown to influence the attitude of consumers towards foreign products (Pullman et al 1997).

The above discussion of PD illustrates that evaluation of products or services from a country is influenced by how the culture, politics, application of laws, economic situation, adequacy of infrastructure and other aspects of the environment in that country, such as language. The above discussion of $\mathrm{COO}$ also suggests that this construct, like PD, may be viewed as a perceptual construct influenced by values as reflected in culture and modified by experience.

\section{Making a Case for Joint Consideration of the Seller's and the Buyer's Origin Perceptions}

Both PD and COO are central international marketing management concepts which are likely to impact on firms' internationalisation. Traditionally approaches to internationalisation focussed on outward driven, mostly export led activities (Cavusgil, 1980; Johanson and Vahlne, 1977, 1993; Piercy, 1981). Then the focus turned to internationalisation from an inward perspective mostly driven by import led activities (Yeoh and Cavusgil, 1990; Rajagopal and Bernard, 1993; Herbig and O'Hara, 1993). A more recent focus has been on internationalisation from an interactive perspective which included linked forms of internationalisation such as strategic alliances, outsourcing, co-operative manufacture and countertrade (Korhonen, Luostarinen and Welch, 1994; Fletcher, 2001).This more holistic focus emphasises the role of linkages and relationships in the internationalisation process. It is in this context that PD and $\mathrm{COO}$ are now considered. PD and COO may play a role with regard to both inward and outward international transactions. Perceptions of PD can impact on buying from an overseas source as well as selling to that source. Perceptions of COO can also impact on both the marketing of domestically manufactures products overseas as well as on foreign made goods in the domestic market (Knight and Calantone, 2000). In addition, Stottinger and Schlegemilch (1998) found that psychological distance between buyers and sellers is asymmetrical and that the "distance to the US market as perceived by a Japanese exporter is not the same as the distance to Japan as perceived by an American importer" (Ellis, 2008, p.356).

As far as PD is concerned, the empirical evidence regarding its influence on issues such as market entry is mixed (Brouthers and Brouthers, 2001). A seminal finding of Tihanyi et al. (2005) was the lack of direct effects of cultural distance and the importance of moderation effects. Specifically, in the abstract they note "Regression results failed to provide statistical evidence of significant relationships between cultural distance and entry mode choice, international diversification, and multinational enterprise (MNE) performance. The examination of moderator effects, however, yielded important results; we found a strong negative association between cultural distance and entry mode choice for US-based MNEs" (Tihanyi et al., 2005, p. 212). Ellis (2008) found that PD did not have a direct link with export market selection. This suggests other forces at work in the interactions involved in market entry.

Concerning COO, Rahman (2001) found that in developing countries such as Bangladesh, country of origin may not translate into buying decisions. In many developing countries, the country of origin can predispose consumers towards imported goods in contrast to developed countries where the effect 
coupled with ethnocentrism is a predisposition towards local products. This also suggests other forces at work such as differences in market structures and consumer behaviours (Ahmed and d'Astous, 1999).

One reason why PD and $\mathrm{COO}$ have been treated as independent concepts may be that most related research has occurred in developed countries (Wang and Chen, 2004). Research has shown that developing countries are more likely to be collectivist (Hofstede, 2001), highly contextual (Hall 1976) and view transactions as being part of a long term relationship as opposed to discrete events (Hofstede and Bond 1988). Firms from collectivist countries also have a history of being more likely to engage in international trade on a reciprocal basis (Fletcher 1996).

The Anholt-GMI study (2005) resulted in the creation of a Nation Brands index which measures the power and appeal of a nation's brand image and argues that this image is a function of tourism, exports, people, governance, culture, heritage, immigration and investment. Although this index of national brand power is intended to apply to buyers, it may also apply to sellers in terms of attractiveness of doing business with a country.

In the same way that $\mathrm{COO}$ affects the buyer's evaluation of the seller's value proposition (Verlegh, Steenkamp and Meulenberg, 2005) it is likely that PD affects the seller's evaluation of the buyer's 'value proposition'. In the same way that information about a country or experience with its products can modify buyers' COO image, knowledge about a country and experience in dealing with its nationals and institutions is likely to modify PD.

A review of the literature on both psychological distance and country of origin reveals that over time there has been a move away from defining these constructs in concrete terms to defining both these constructs in perceptual terms. In general terms, $\mathrm{PD}$ is a seller decision-making variable whereas $\mathrm{COO}$ is a buyer decision making variable. Both are perceptual constructs and it does not seem to far-fetched to suggest that a positive relationship will depend on these two perceptions being in harmony. If PD influences perceptions on the part of the seller or exporter and COO influences perceptions on the part of the buyer or importer in an international relationship, then it would seem that both aspects of the relationship should be considered in the pursuit of a better understanding of international business.

Our literature review further reveals that there are a number of underlying factors that could be common to both PD and COO. These are language, culture, business customs and practices, the political system and its operation, the financial condition of the market, economic indicators, infrastructure and its availability, level of education and training, prior experience with the country or market for the product category, and availability of information. Another issue for consideration is that of information asymmetry in a proposed international transaction. COO Perceptions often substitute readily available information on a country, and perceptions of PD are often driven by lack of information about a country. Both constructs can be substitutes for information and both diminish in importance when factual information is available. According to the literature, both concepts are heavily influenced by culture which in turn reflects the values of the society (Low and Fletcher, 2004). The values of the importer re $\mathrm{COO}$ will interact with the values of the exporter re PD.

\section{Illustration of the Potential for Interaction between PD and COO}

The potential for interaction between perceptions of $\mathrm{COO}$ and PD is explored in a review of two international transactions based on exploring the networks of relationships involved in the transactions. The value in seeing the business relationship as the unit of analysis, and thus viewing these two concepts as 'two sides of a coin', is that business practitioners gain more realistic insight into the effects of these constructs as they apply in the international market place. The network paradigm may serve as underlying theoretical framework where a more holistic view is especially critical.

The operation of the network paradigm in international marketing is based on co-operation between importer and exporter rather than competition and this presupposes that each party is sensitive to the perceptions of the other. The network paradigm is anchored in the concept of relationships where the driver is co-operation to create value for both importer and exporter. There is the notion of continuous 
interaction between importer and exporter to create mutual advantage and the viewing by both parties of the other as a relationship partner.

The principal relationship between the importer and the exporter is linked to the other relationships each of the parties have. It is the totality of these relationships that form the wider network. It is within this wider network that the "offerings of each company are developed, bought, sold, added to, refined, combined and sold onto others until they reach a final customer. The relationship between a single customer and supplier in the network will be affected by that customer's relationships with its own customers and the supplier's relationships with its own suppliers" (Ford et al 2003).

This pattern of relationships would suggest that a concept impacting on the importer will be related to a concept impacting on the exporter and that this is likely to be reflected in the network paradigm especially when both parties to the focal relationship have elements in common.

As such, the networks in which exporter and importer are embedded may be useful for addressing perceptions of $\mathrm{PD}$ and $\mathrm{COO}$ in the context of the business relationship. It is argued that many parties in the network in which the importer is embedded are likely to be influenced by perceptions of the COO regarding the goods/services on offer and several parties in the network in which the exporter is embedded are likely to be influenced by perceptions of PD between their home country and the country from which the goods/services might be supplied. It is when the importer network becomes linked in a potential transaction to the exporter network that COO perceptions mesh with PD perceptions.

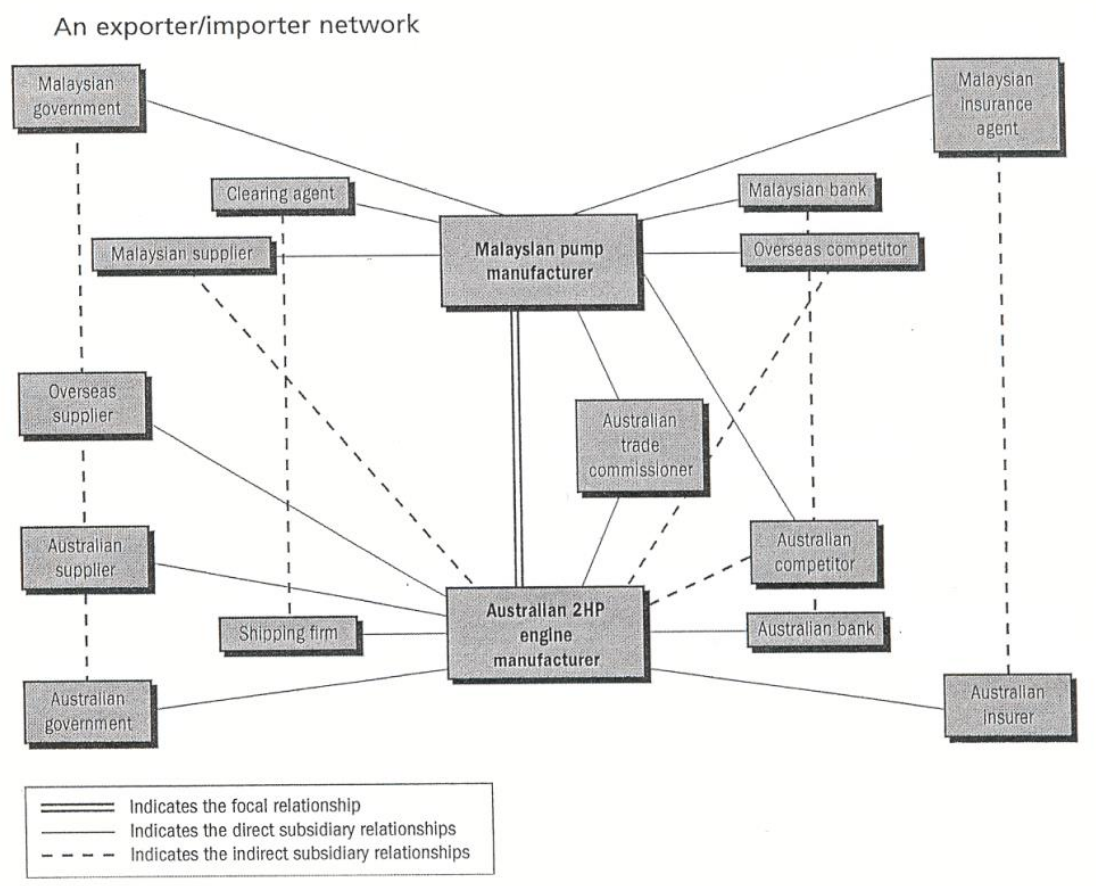

Figure 1: Network Map (Fletcher and Brown 2008, p.479)

Figure 1 illustrates this by depicting a network map of a typical export/import transaction between an Australian producer of $2 \mathrm{hp}$ engines for pumps and a Malaysian manufacturer of pumps. In this figure, not only the Malaysian pump manufacturer, but indirectly all other parties located in the Malaysian pump manufacturers network (government, suppliers, facilitators, financial institutions, competitors etc) are likely to be influenced by perceptions of Australia as a country of origin for pump engines. Likewise, not only the Australian engine producer, but also other parties located in the Australian engine producer's network (government, competitors, suppliers, facilitators, financial institutions etc) are likely to be influenced by perceptions of Malaysia's attractiveness as a market in terms of its psychological distance from Australia. There are, in addition, mediating influences: As an illustration, the views of other parties in Malaysia who have had experience dealing with Australia and conversely 
the views of other parties in Australia who have had experience dealing with Malaysia, may influence the parties to the focal import/export relationship as far as COO and PD are concerned.

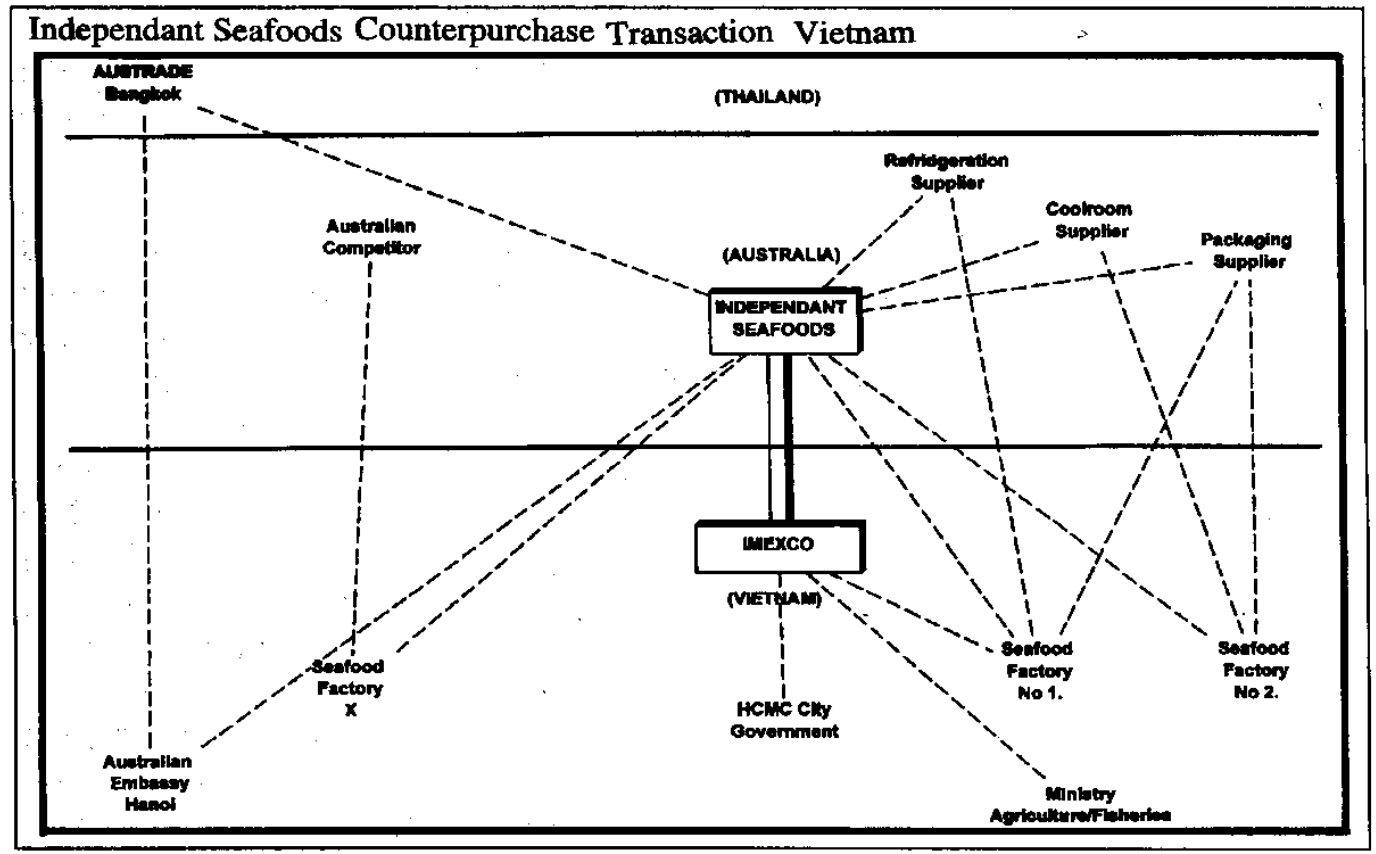

Figure 2: Vietnamese Seafood case-study (Fletcher, 1996, p.315)

Figure 2 illustrates this in the case of seafood exported from Vietnam to the Australian market based on counter-trade. The Vietnamese seafood producer as well as other parties located in the Vietnamese seafood producer's network is likely to be influenced by Australia's attractiveness as a market in terms of its PD from Vietnam. Likewise, not only the Australian seafood importer, but indirectly all other parties in the Australian seafood importer's network are likely to be influenced by perceptions of Vietnam as a $\mathrm{COO}$ for seafood. This case shows that one way of overcoming problems of both COO and PD may be to move to a more resource intensive mode of international involvement beyond the import/export transaction. It illustrates a counter-trade transaction between a Vietnamese seafood producer and an Australian seafood importer. When circumstances in the overseas market do not permit the free flow of trade, often devices such as counter-trade are employed whereby reciprocal obligations are formalised into a conditional arrangement without which the business cannot occur. At the time of this case research, Vietnam was an unknown source of supply of seafood in the Australian market and had a negative country of origin image compared to other current sources of supply such as Malaysia and Thailand due to memories of the Vietnam war, its communist background, its economic situation and the flight of refugees into Australia. From the perspective of the Vietnamese seafood producer in 1987, Australia was psychologically distant from Vietnam and not considered as an export destination as the product had traditionally been caught and sold rather than marketed internationally and mostly to trading partners in the communist bloc. These issues were addressed by the Australian firm (Independent Seafoods) establishing an operation in Vietnam that oversaw the catching of the shrimp, the handling of the product in a manner that met Australian health and quarantine requirements, the branding of the product with an established brand used by Independent Seafoods when marketing products in Australia and marketing the product in Australia in a way that would reduce $\mathrm{COO}$ concerns when the seafood was sold in the Australian marketplace.

\section{Implications and Future Research}

The traditional approach to marketing (e.g. Kotler, 1988) views it in terms of actions by producers that cause buyers to react. More recent approaches to marketing (e.g. Peck, Payne, Christopher and Clark, 2000; Quester, McGuiggan, Perault and McCarthy, 2007) recognise that it is more complex and focus more on interaction and cooperation between buyer and seller rather than on the reaction of the buyer 
to the offerings of the seller. Concepts such as buyer loyalty, customer relationship management, customisation as well as new technologies for communicating with the customer such as the Internet, demonstrate that the traditional approach to marketing is becoming less relevant and that it is interaction rather than reaction which operates in markets where buyers have choice regardless of whether it is an offering directed at consumers or industrial buyers.

Unfortunately, there are still hangovers from more traditional approaches to marketing, one of which is the treatment of a number of marketing concepts as discrete when in fact they are interrelated as far as the practice of marketing is concerned. In part this is due to a focus on the marketing activity rather than on the markets themselves; this requires market sensing involving monitoring market trends, learning from them and proactively responding to opportunities and threats (Cravens 2005).

Based on the above discussion, we present four propositions in order to illustrate the concrete implications and research opportunities that arise from the looking simultaneously at both sides of the coin. Research (Gripsrud, 1990; Nordstrom and Vahlne, 1994; Stottinger and Schlegelmilch, 2000) shows that PD plays a role to exporting companies such that the attraction of a foreign market is more attractive the lower the psychological distance. Researchers (for reviews see Peterson \& Jolibert, 1995; Pharr, 2005) show that the COO effect plays a role for the customer in both consumer and business-to-business markets: The more positively the costumer evaluates the origin of the offering, relatively more attractive is the offering perceived. Thus, the following is proposed:

P1: The international transaction is more attractive to both the selling and the buying firm the more positively they perceive the origin of the trade partner's firm.

Cultural group attraction theory (Byrne, 1971; Newcomb, 1956) suggests that individuals are more attracted to things, individuals and groups which they perceive as being similar. Drawing on attraction theory, we suggest that both the selling and the purchasing company are more likely to enter into negotiations the more they perceive a cultural similarity.

P2: The possibility of firms from different origins entering into business negotiations is higher the more positively either firm perceives the origin of the other firm.

We draw on attitude theory for proposition three. Attitude theory defines attitude as "a learned predisposition to respond in a consistently favourable or unfavourable manner with respect to a given object" (Fishbein \& Ajzen, 1975, p. 6). This can apply to both PD and COO. While the COO of an offering generally is an important extrinsic cue (Verlegh \& Steenkamp, 1999), it is not always a critical cue and for some offerings it may not be a relevant issue at all. A similar argument can be mounted with respect to PD. In general, however, the individuals involved in the negotiations will experience a degree of cognitive dissonance if positive attitudes towards the origin and distance do not lead to sales.

P3: The possibility of negotiations resulting in actual trade is higher the more positive either firm perceives the origin of the other firm.

The creation of relationships between exporters and importers is based on both parties building up knowledge about each other (Hakansson, 1982, Easton 1992). The interactions between these participants form network patterns that stretch across cultures (Ford et al, 1986) thus lessening perceptions of difference. The resulting relationships often involve interdependency, a longer time horizon and a need for both importers and exporters to learn about each other. This facilitates not only the international sales transaction but also the access of resources from each other (Fletcher, 1996).

P4: When both parties have a relationship focus either party is likely to perceive the other party's origin more positively.

\section{Conclusion}

From the practitioner perspective, international marketing managers need to explore the potential for interaction between purportedly discrete marketing concepts so as to better understand how international marketing actually takes place. This requires that managers explore the networks which exist and mesh in an international business transaction. The network paradigm with its focus on 
relationships and interaction is a possible framework for exploring the roles of PD and COO. Indeed international marketing management involves dualities based on interactions and cooperation rather than discrete concepts separately influencing the buyer (e.g. importer) and the seller (e.g. exporter). If the international marketer applies the underlying variables that influence his perceptions regarding the potential transaction to the likely perception of the transaction from the perspective of the importer, then the international marketer will both have a better appreciation of the interaction involved and an improved prospect of bringing the international transaction to a successful conclusion. As such, further research is needed to empirically examine our conjunctures. It is suggested that this involve asking a cross section of those who both import and export about the degree of importance they place on each of the factors from the literature that appear common to PD and $\mathrm{COO}$ as influencing their perception of the other party to the transaction (viz language, religion, education, level of development in other country and other country's political system and its operation). Investigating these concepts as central influencers of a transaction within a network rather than separate constructs involving discrete parts to the transaction is likely to be a major task for researchers, but the rewards for theory and practice could be considerable.

\section{References}

Acharya, C. and G.Eliott (2001) "An Examination of the Effects of 'Country of Design' and 'Country of Assembly' on Quality Perceptions and Purchase Intentions”, Australasian Marketing Journal, 9 (1), 61-73.

Ahmed, A. and d'Astous, A (1999) "Product-Country Images in Canada and in the People's Republic of China". Journal of International Consumer Marketing, 11(1), 5-22.

Al-Sulaiti, K.I. and Baker, M.J. (1998) "Country of origin effects: A Literature review", Marketing Intelligence and Planning, 16(3) 150-99.

Anholt, S. (2005) "Anholt-GMI Nation Brands Index - Second Quarter, http://www.gmimr.com/gmipoll/nbi.phtml

Al-Sulaiti, K. I., \& Baker, M. J. (1998). Country of origin effects: a literature review. Marketing Intelligence \& Planning, 16(3), 150.

Bilkey, Warren J and Erik Nes (1982), "Country-of-origin effects on product evaluations," Journal of International Business Studies, 13 (1), 89-100.

Brewer, P. (2004) "Operationalising Psychological Distance", Proceedings of the ANZIBA Conference, November 5-6, University of Canberra,Canberra.

Byrne, D. (1971). The attraction paradigm. New York: Academic Press.

Brouthers, K.D. and Brouthers, L.E. (2001) "Explaining the National Cultural Distance Paradox", Journal of International Business Studies, (32), 177-91.

Byrne, D. (1971), The attraction paradigm. New York: Academic Press.

Cavusgil, S.T. (1980) “On the Internationalisation Process of Firms”, European Research, 8 (6), 273 81.

Chetty, S. and C.Campbell-Hunt. (2004) "A Strategic Approach to Internationalisation: a Traditional vs a Born Global Approach", Journal of International Marketing, 12 (1), 57-81.

Crnjak-Karanovic, B., A. Pecotich and N. Renko, (2005) "Understanding the Dimensions of country of Origin Judgements: A Preliminary Evaluation", Proceedings of the World Marketing Congress, July 6-9, Munster, Academy of Marketing Science.

Dow, D. and Karunaratna, A. (2006) "Developing a Multidimensional Instrument to Measure Psychological distance Stimuli", Journal of International Business Studies, 37 (5), 578-02.

Easton, G. (1992) "Industrial networks: A Review" in B. Axelsson and G.Easton (Eds) Industrial networks: A New Reality, Routledge, London.

Ellis, P.D. (2008) "Does Psychological Distance Moderate the Market Size-Entry Sequence Relationship?" Journal of International Business Studies, 39, 351-69.

Evans, J. and F.T. Mavondo (2002) "Psychological Distance and Organizational Performance: An Empirical Examination of International Retailing Operations", Journal of International Business Studies, 33 (3), 515-32.

Fishbein, M., \& Ajzen, I. (1975). Attitude, Intention and Behaviour: An Introduction to Theory and Research. MA: Addison-Wesley. 
Fletcher, R. (1996) "The Impact of Countertrade on the Internationalisation of the Australian Firm", unpublished $\mathrm{PhD}$ thesis, University of Technology, Sydney.

Fletcher, R. and J. Bohn (1998). "The Impact of Psychological Distance on the Internationalisation the Australian Firm", Journal of Global Marketing, 12(2), 47-68.

Fletcher, R. (2001), “A Holistic Approach to Internationalisation”, International Business Review, 10, 25-99.

Fletcher, R. and J. Bell (2002) "Hijacking Country of Origin Image" Proceedings of the annual of the Australian Firm",.Conference of the Academy of Marketing, UK, $2^{\text {nd }}-5^{\text {th }}$ July, University of Nottingham.

Fletcher, R. and L. Brown (2008) International Marketing - An Asia-Pacific Perspective, $4^{\text {th }}$ Edition, Pearson Prentice Hall, Sydney.

Ford, D., L-E Gadde, H.Hakansson, and I. Snehota (2003) Managing Business Relationships, Ed 2. John Wiley \& Sons, West Sussex, UK.

Georgas, J., F.J.R Van der Vijver, and J.W.Berry (2004) "The Ecocultural Framework, Ecosocial Indicies and Psychological Variables in Cross-Cultural Research", Journal of Cross-Cultural Psychology,35 (1) 74-96.

Gripsrud, G. (1990) "The Determinants of Export Decisions and Attitudes to a Distant Market Norwegian Fishery Exports to Japan”, Journal of International Business Studies,23 (3), 469-85.

Gronroos, C. (2000) Services Management and Marketing: a Customer Relationship Management Approach, Ed 2, John Wiley \& Sons, West Sussex, UK.

Gurhan-Canli, Z. \& Maheswaran, D. 2000a. Determinants of country-of-origin evaluations. Journal of Consumer Research, 27(1): 96-108.

Gurhan-Canli, Z. \& Maheswaran, D. 2000b. Cultural variations in country of origin effects. Journal of Marketing Research, 37(3): 309-31.

Hakansson, H.(1982) Industrial marketing and purchasing of Industrial Goods- An Interaction Approach, John Wiley, Chichester.

Hall, E.T. (1976) Beyond Culture, Anchor Press/Doubleday, New York.

Han, C.M. (1989) "Country Image: Halo or Summary Construct/", Journal of Marketing Research, 26(2) 222-29.

Han, C.M. and V. Terpstra. (1988) "Country of origin effects for Uni-National and Bi-National Products", Journal of International Business Studies, 19, Summer, 235-55.

Herbig, P.A. and O'Hara, B.S. (1993) "International Procurement - a Matter of Relationships", Marketing Intelligence and Planning, 2 (7), 39-43.

Hofstede, G. (2001) Culture's Consequences: Comparing values, behaviours, institutions and organizations across nations, Sage Publications, Thousand Oaks, California.

Hofstede, G. and M.H. Bond. (1988) "The Confucious Connection: from Cultural Roots to Economic Growth", Organizational Dynamics, 16 (4), 4-21.

Holzmuller, H. and P.Lenz. (2004) "Transferring an International Construct to a local Context: Descriptive and Causal Insights on City of Origin Effects in the German Beer Market", Proceedings of the Industrial Marketing and Purchasing Group Conference, September 1-4, Copenhagen Busines School, Copenhagen.

Johansson, Johny K, Susan P Douglas, and Ikujiro Nonaka (1985), "Assessing the impact of country of origin on product evaluations: A new methodological perspective," Journal of Marketing Research, 22 (4), 388-96.

Johanson, J. and Vahlne, J.E. (1977) "The Internationalisation Process of the firm - a Model of Knowledge Development and Increasing Foreign Market Commitments", Journal of International Business Studies,. Spring/Summer 23-32.

Johanson, J, and F. Wiedersheim-Paul (1975). " The Internationalisation Process of the Firm - Four Swedish Case Studies". The Journal of Management Studies, 12 (3),.305-22.

Josiassen, Alexander, Bryan A. Lukas, and Gregory Whitwell (2008), "Country-of-Origin Contingencies: Competing Perspectives on Product Familiarity and Product Involvement," International Marketing Review, 25 (4), 423-40.

Josiassen, Alexander P. and Ingo O. Karpen (2007), "The Country-of-Origin Concept: The Historical Approach to Identifying Future Research Challenges," in Australian and New Zealand Marketing 
Association Conference (ANZMAC) Proceedings, Otago University Press (Ed.). Dunedin, New Zealand.

Josiassen, A. \& Harzing, A.-W. 2008. Descending from the Ivory Tower: Reflections on the relevance and future of country-of-origin research. European Management Review, 5(4): 264-70.

Kotler, P. (1988) Marketing Management, Analysis, Planning and Control, Prentice hall, new Jersey.

Korhonen, H., Luostarinen, R. and Welch, L.S. (1994) "Inward-Outward Internationalisation: Patterns and Government Policies for Finnish SME's" Paper presented at the Annual Nordic Marketing Conference, Umea. November.

Knight, G.A. and Calentone, R.J. (2000) "A Flexible model of Consumer Country of Origin Perceptions", International Marketing Review,17 (2), 127-45.

La, V., P. Patterson and C. Styles (2004) "Impact of Country of Origin on Client Perceived Performance in International Professional B2B Services". Paper presented at the Conference of the Australia New Zealand Marketing Academy, November 29 - December 1, Victoria University, Wellington, NZ.

Li, Zhan G, L William Murray, and Don Scott (2000), "Global sourcing, multiple country-of-origin facets, and consumer reactions," Journal of Business Research, 47 (2), 121-33.

Low, D. and R. Fletcher, R. (2003) "Is Hofstede Relevant in the New Millennium?", Conference of the European Marketing Academy, May 20-23., University of Strathclyde, Glasgow.

Low, D. and R. Fletcher. (2004) “Acculturation, Individualism and the Nation State", Paper presented at the Conference of the Australia New Zealand Marketing Academy, November 29 - December 1, Victoria University, Wellington, NZ.

Mort, G.S. and M.Duncan. (2000) "The Country of Origin Effect: A Study of the 'owned by...' Cue", Proceedings of the Conference of the Australian and New Zealand Marketing Academy, December 4-7, Griffith University, Gold Coast.

Nagashima, Akira (1977), "A comparative "made in" product image survey among Japanese businessmen," Journal of Marketing, 41 (3), 95-100.

Newcomb, T. M. (1956), "The prediction of interpersonal attraction," American Psychologist, 11 (1), $575-86$.

Nordstrom, K. and Vahlne, J.E. (1994) "Is the Globe Shrinking? Psychological distance and the Establishment of Swedish Sales Subsidiaries During the Last 100 Years", In M.Landek (Ed) International Trade: Regional and global Issues,41-56. New York, St Marten's Press.

O'Grady, S. and H.W.Lane. (1996) "The Psychological Distance Paradox", Journal of international Business Studies, 27(2) 309-33.

Okechuku, Chike and Vincent Onyemah (1999), "Nigerian consumer attitudes toward foreign and domestic products," Journal of International Business Studies, 30 (3), 611-32.

Ozsomer, A and St Cavusgil (1991), "Country-of-origin effects on product evaluations: A Sequel to Bilkey and Nes Review," Proceedings of the American Marketing Association Conference, 269-77.

Peck, H., A. Payne, M. Christopeher, and M. Clark. (2000) Relationship Marketing: Strategy and Implementation, Butterworth Heineman, Oxford.

Pereira, C. (2004) "Export Marketing Strategy: Does Psychological distance Matter?", Proceedings of the Conference of the European Marketing Academy, May, University of Murcia, Murcia, Spain.

Peterson, R.A. and A.J.P. Jolibert (1995) "A Meta-Analysis of Country of Origin Effects", Journal of international Business Studies, Fourth Quarter, 883-900.

Pharr, Julie M. (2005), "Synthesizing Country-of-Origin Research from the last Decade: Is the concept still Salient in an Era of Global Brands?," Journal of Marketing Theory \& Practice, 13 (4), 34-45.

Piercy, N. (1981) "Company internationalisation: Active and Reactive bExporting", European Journal of Marketing, 15(2), 44-56.

Pullman, M.E. and K. Granzinb (1997) "The Efficacy of Cognition and Emotion-Based 'Buy Domestic' Appeals: Conceptualisation, Empirical Test and Managerial Implications”, International Business Review,6 (3) 209-31.

Quester, P.G., R.L.McGuiggan, W.D.Perrealt.,and E.J.McCarthy (2007) Marketing Creating and DeliveringVvalue, McGraw Hill Irwin, Australia.

Rahman, S. (2001) Country of Origin Effect in Developing Countries - Does it Really Matter? Proceedings of ANZMAC Conference, $1^{\text {st }}-5^{\text {th }}$ December, Massey University, Auckland, New Zealand. 
Rajgopal, S. and Bernard, K.N. (1993) "Globalization of the Procurement process", Marketing Intelligence and Planning, 11 (7), 44-56.

Rokeach, M. (1968) Beliefs, Attitudes and Val;ues, Jossey-Bass, San Francisco, CA.

Rokeach, M. (1973) The Human Nature of Values, Free Press, New York.

Schwartz, S.H. (1992) "Universals in the Content and Structure of Values: Theoretical Advances and Empirical tests in 20 Countries" in Advances in Experimental Social Psychology" M.P.Zana, Ed. Vol 25, Orlando, Academic Press.

Shimp, Terence A. and Subhash Sharma (1987), "Consumer Ethnocentrism: Construction and Validation of the CETSCALE," Journal of Marketing Research, 24 (3), 280-89.

Shrimp, T. and S. Sharma. (1994) "Consumer Ethnocentrism: Construction and Validation of the CETSCALES", Journal of Marketing Research,26, August, 280-89.

Sousa, C.M. and F. Bradley (2003) "Cultural Distance and Psychological Distance Dilemma", paper presented at the $32^{\text {nd }}$ EMAC Conference, 20-23 May, University of Strathclyde, Glasgow.

Stottinger, B and Schlegmilch, B.B. (1998), "Explaining Export Development Through Psychological Distance: Enlightening or Elusive?”, International Marketing Review, 15(5) 169-73.

Tihanyi, L., Griffith, D.A. and Russell, C.J (2005) "The Effect of Cultural Distance on Entry Mode Choice, international diversification, and MNE Performance", Journal of International Business Studies, (36), 270-83.

Tse, D.K. and G.J.Gorn. (1992) "An Experiment in the Salience of Country of Origin in the Era of Global Brands", Journal of International Business Studies, 1(4) 57-76.

Usunier, Jean-Claude (2006), "Relevance in business research: the case of country-of-origin research in marketing," European Management Review, 3 (1), 60-73

Verlegh, Peeter W J and Jan-Benedict E M Steenkamp (1999), "A review and meta-analysis of country-of-origin research," Journal of Economic Psychology, 20 (5), 521-46.

Verlegh, P.W.J., Steenkamp, J-B, E.M. and Meulenberg, M.T.G. (2005) 'Country of Origin Effects on Consumer Processing of Advertising Claims', International Journal of Research in Marketing, Vol 22, pp.127-139.

Wang, C.L. and Chen, Z.X. (2004) "Consumer Ethnocentrism and Willingness to Buy Domestic Products in a Developing Country Setting: Testing Moderating Effects", Journal of Consumer Marketing, 21(6) 391-400;

Welch, D., L. Welch, I.F. Wilkinson and L.C. Young (1996) "Network Development in International Project Marketing and the Impact of External Facilitation", International Business Review, 5 (6), 579-602.

Welch, D., L. Welch, I.F. Wilkinson and L.C. Young (1998) "The Importance of Networks in Export Promotion: Policy Issues", Journal of International Marketing, 6 (4) 66-82.

Yeoh, P.L. and Cavusgil, T.S. (1990) "Global Sourcing Entry Strategies: A Contingency Approach Based on Transaction Cost Analysis", Proceedings of the Summer Conference of the American Marketing Association. 